\title{
Exploratory Analysis of Urban Sustainability by Applying a Strategy-Based Tailor-Made Weighting Method
}

\author{
Attila Buzási *(D) and Bettina Szimonetta Jäger \\ Department of Environmental Economics, Budapest University of Technology and Economics, \\ 1111 Budapest, Hungary; jager.szimonetta@gtk.bme.hu \\ * Correspondence: buzasi.attila@gtk.bme.hu
}

Citation: Buzási, A.; Jäger, B.S Exploratory Analysis of Urban Sustainability by Applying a Strategy-Based Tailor-Made Weighting Method. Sustainability 2021, 13, 6556. https://doi.org/ $10.3390 /$ su13126556

Academic Editor: Ayyoob Sharifi

Received: 7 May 2021

Accepted: 4 June 2021

Published: 8 June 2021

Publisher's Note: MDPI stays neutral with regard to jurisdictional claims in published maps and institutional affiliations.

Copyright: (c) 2021 by the authors. Licensee MDPI, Basel, Switzerland. This article is an open access article distributed under the terms and conditions of the Creative Commons Attribution (CC BY) license (https:/ / creativecommons.org/licenses/by/ $4.0 /)$.

\begin{abstract}
The Hungarian cities are rarely analyzed in current urban studies, especially in terms of urban sustainability. The present study aimed at analyzing the Hungarian county seats by comparing them through economic, social, and environmental indicators, which cover a broad spectrum of urban sustainability by applying independent indicators. Altogether 30 variables have been involved from 2014 and 2018-2019 to reveal the regional pattern of urban sustainability among the Hungarian county seats by applying the strategy-based tailor-made (SBTM) weighting methodology. It takes into consideration the different emphases regarding local aspects and main issues of sustainability through the analysis of integrated settlement development strategies, which is a unique method compared to current approaches. After the evaluation of the results, it can be stated that the east-west axis was revealed regarding weighted and unweighted sustainability indices; furthermore, a highly heterogeneous spatial trend can be drawn with regard to the relative changes in urban sustainability performance without clearly defined regional clusters. This analysis can fill the current literature gap by analyzing the Hungarian context and elaborating an easy-to-use weighting methodology based on the cities' development strategies which contribute to improving the variety of planning and decision-making tools in the field of urban development.
\end{abstract}

Keywords: urban sustainability; indicator; regional patterns; weighting method

\section{Introduction}

Urban areas play a pivotal role in achieving sustainability goals not only worldwide but also on the local level because the concentration of people, economic activity, and environmental issues are considered as distinguished sustainability-related challenges [1-3]. Mainstreaming sustainability in the decision-making processes of urban areas is a clear and accepted process to accelerate the global and local transitions towards a more resourceefficient socioeconomic system [4-6]. Besides specific challenges, considerable progress has been made in urban sustainability studies during the last decades with an increasing number of assessment case studies and methodologies [7], which pointed out the most relevant challenges and opportunities in this research area [8]. The growing number of studies draws attention to governance- and institutional-related issues $[9,10]$, which encompass practice-oriented and easy-to-use methodologies by applying widely available indicators or indices to describe the sustainability of a given city or to compare different urban areas [11,12]. Consequently, an unquestionable need to elaborate methodologies can be applied to perform nationwide analysis of urban sustainability or compare cities from different regions and countries. Comparative analyses regarding urban sustainability can be found in a constantly growing number in the literature from Asia [13-15], Europe [16-18], Latin America [19], Africa [20-22], North America [23-25], and Australia [26,27].

In the following paragraphs, selected papers are shortly introduced after a solid literature review, grouped around three main aspects: the rarely studied Hungarian context, indicator selection issues, and different weighting methodologies regarding urban sustainability analyses. All the revised papers are available in English and indexed by Scopus or 
Web of Science. It can be seen that the urban sustainability assessment practices have been well documented; however, the Hungarian context is still less actively studied:

- Kiss (2015) [28] performed a detailed analysis of energy-related interventions from Pécs, Hungary. Although his paper focused on a given sustainability aspect at the city level, it cannot be treated as a comprehensive urban sustainability analysis;

- $\quad$ Sebestyén, Somogyi, Szőke, and Utasi (2018) [29] used the SDEWES index to describe the sustainability of two Hungarian cities by involving 35 indicators in 7 categories. It is unquestionably a comparison-based analysis; however, the applied methodology is not unique concerning the Hungarian context; furthermore, it encompasses only two cities;

- $\quad$ Ehnert, Frantzeskaki et al. (2018) [10] analyzed five European cities (one of them was Budapest) in terms of urban sustainability transition aspects by comparing planningoriented activities;

- three Hungarian cities, namely Győr, Pécs, and Miskolc, have been involved in governance- and development-oriented analysis conducted by Lux (2015) [30];

- Bajmócy, Gébert, Málovics, Berki, and Juhász (2020) [31] assessed urban strategic planning issues in Hungary by paying attention to practice-oriented features of Pécs, Szeged, and Kecskemét;

- Kovács et al. (2019) [32] focused on urban sprawl patterns in case of Budapest as one of the most relevant sustainability challenges regarding the Hungarian capital;

- finally, Buzási and Jäger (2020) [33] applied a 30-indicator assessment methodology to describe the overall and sustainability dimensions-related performance of the districts of Budapest.

The listed Hungary-specific studies applied various methodologies to conduct sustainability-based evaluations regarding the selected cities as case studies. The pool of the analyzed urban areas seems to be relatively narrow with a strong Budapest and Pécs emphasis. The methodology-related heterogeneity can be found in the international literature as well; however, the selection of indicators and weighting techniques are the two most commonly mentioned cornerstones of current urban sustainability studies. CorredorOchoa, Antuña-Rozado, Fariña-Tojo, and Rajaniemi (2020) [34] defined the eight most relevant challenges with regards to indicator-based analyses as the followings: confusion between sustainable development and urban sustainability; complexity within urban planning; difficulties in finding indicators; lack of indicators; describing all aspects of relevant stakeholders; challenges in using indicators or indices; commercial urban certifications; insufficiency and incomparability of data. The main aim of current sustainability-based urban studies can be described as avoiding the oversimplification of the complex assessed systems. Therefore, numerous different solutions can be found in the literature regarding the number of indicators and involved sustainability dimensions based on the analyzed context and data availability features [35-38]. According to the revised literature, it can be concluded that the too large pool of selected indicators heavily hinders the widespread applicability of the elaborated urban sustainability method; however, the opposite direction regarding the number of variables oversimplifies a highly complex system. Besides the indicator-selection challenges, elaborating the applied weighting methodology is another crucial phase of urban sustainability evaluations [13]. Gan et al. (2017) [39] conducted a detailed literature review, focusing on weighting and aggregating methods of urban sustainability indicators. According to their study, eight major weighting methods can be defined after reviewing the related literature: equal weighting, principal component analysis, the benefit of the doubt approach, regression analysis, unobserved component models, budget allocation, public opinion, analytical hierarchy process, and conjoint analysis. These methodologies have several strengths and limitations; however, they are applied widely in current urban studies. In addition, Sharifi, Dawodu, and Cheshmehzangi (2021) [40] summarized the main limitation with regards to assessment methodologies of an urban sustainability analysis tool and emphasized the limited consideration of context-specific issues. It can be stated that-besides the debate regarding the appropriate number of urban 
sustainability indicators-selection of a too complex and specific weighting methodology contributes to reducing the transfer potential of the elaborated assessment methodology. Thus, this paper aims to develop such a weighting method that can be adapted to other cases easily by paying attention to local-specific aspects while not oversimplifying the related issues of the broader urban sustainability context.

After revising the existing literature, it became apparent that comparative urban sustainability analysis of Hungarian cities has not yet been considered; moreover, contextspecific issues shall be involved by applying a weighting method to distinguish the notequally-relevant sustainability aspects on the local level. Thus, a strategy-based tailor-made (SBTM) weighting methodology has been elaborated to pay more attention to local- and context-specific aspects of the analyzed cities and fill the before mentioned methodological gap. Having said the above, this study aims to assess the urban sustainability of the Hungarian county seats by applying the indicator method with the SBTM weighting technique for 2014 and 2018/19. This spatiotemporal analysis can fill the gap in the current literature regarding (1) the lack of the Hungarian context and (2) its contribution to elaborate an easy-to-use weighting methodology based on the cities' development strategies; consequently, it helps to improve the decision-making and planning processes in the field of regional and urban development.

\section{Materials and Methods}

In the following paragraphs, the main methodological issues will be introduced: firstly, the study area will be defined, then the selected indicators will be introduced; finally, the elaborated SBTM weighting methodology will be interpreted. In the field of urban sustainability analysis, a wide range of applied sets of indicators is available. This finding is particularly valid in studies focusing on comparing elements falling under a higher territorial unit, such as our case because the study area of this paper is the list of the Hungarian county capitals. As it was previously stated, the Hungarian context is rarely studied; furthermore, comparative analysis regarding Hungarian county seats is not available yet in the literature. This paper focuses on revealing regional patterns of urban sustainability; consequently, NUTS-2 regions have been dedicated as a spatial basis for further analyses, as planning and statistical regions. Hungary is divided into eight NUTS-2 regions which cover 19 counties with their capitals (see Figure 1). The eight NUTS-2 regions are Western Transdanubia (Győr, Szombathely, Zalaegerszeg), Central Transdanubia (Tatabánya, Székesfehérvár, Veszprém), Southern Transdanubia (Pécs, Kaposvár, Szekszárd), Southern Great Plane (Kecskemét, Békéscsaba, Szeged), Northern Great Plane (Debrecen, Szolnok, Nyíregyháza), Northern Hungary (Miskolc, Eger, Salgótarján), Pest and Budapest. It is worth mentioning that from 1 January 2018, the former Central Hungary region was divided into Pest and Budapest. Budapest is the capital city of Hungary and a region itself, and thus in the following, Pest is omitted from the further demonstration of results regarding the regions.

The analyzed cities vary in terms of their area and population, as shown in Table 1. According to the population and area, Budapest excels from the other cities, which is not surprising given it is the capital city of Hungary. Regarding the area size (except for Budapest due to its outstanding values) Debrecen, Kecskemét, Szeged, Nyíregyháza, Miskolc, Békéscsaba, Szolnok, Győr, Székesfehérvár, Pécs, Veszprém, Kaposvár, and Zalaegerszeg belong to the superior group because their area size is above $100 \mathrm{~km}^{2}$. Considering the population, Debrecen, Szeged, Miskolc, Pécs, Győr, Nyíregyháza and Kecskemét have higher values, as the number of their inhabitants are over 100,000. In Western Transdanubia (Györ, Szombathely, Zalaegerszeg), Győr stands out regarding its population size $(124,287$ inhabitants), but the three cities' average value is still high $(\sim 85,000)$. Győr also has the highest value in terms of the area $\left(174.62 \mathrm{~km}^{2}\right)$, while the average value is approximately $125 \mathrm{~km}^{2}$. In Central Transdanubia (Tatabánya, Székesfehérvár, Veszprém), the largest size of the population (95,714 inhabitants) belongs to Székesfehérvár, while the average is about 73,000 inhabitants. According to the area size, Székesfehérvár is well above the 
average $\left(\sim 130 \mathrm{~km}^{2}\right)$ with a value of $170.89 \mathrm{~km}^{2}$. In Southern Transdanubia (Pécs, Kaposvár, Szekszárd), Pécs stands out with 146,721 inhabitants and an area of $162.78 \mathrm{~km}^{2}$, while the average is nearly 80,000 inhabitants and $124 \mathrm{~km}^{2}$. In Southern Great Plane (Kecskemét, Békéscsaba, Szeged), Szeged has a much larger population (161,755 inhabitants) than the average value $(\sim 110,300)$, despite the size of the area, in which Kecskemét has the highest value with $322.57 \mathrm{~km}^{2}$, while the average is $265 \mathrm{~km}^{2}$. In Northern Great Plane (Debrecen, Szolnok, Nyíregyháza), Debrecen is well above the region's average values $\left(\sim 130,000\right.$ inhabitants and $\left.\sim 308 \mathrm{~km}^{2}\right)$. The city has 201,081 inhabitants, and its area is $461.66 \mathrm{~km}^{2}$. According to the population and area size of Northern Hungary (Miskolc, Eger, Salgótarján), Miskolc owns the largest population (157,544 inhabitants) and area $\left(236.67 \mathrm{~km}^{2}\right)$. Eger and Salgótarján are similar in size and population and below-average values $\left(\sim 81,400\right.$ inhabitants, $\left.\sim 142 \mathrm{~km}^{2}\right)$. As it was mentioned before, in 2018 , Budapest became an independent region, and because the region consists only of Budapest, we cannot present a comparison as before. It is not surprising that Budapest has the highest number of inhabitants $(1,704,649)$, but despite the large population, its area $\left(525.14 \mathrm{~km}^{2}\right)$ is barely larger than Debrecen's $\left(461.66 \mathrm{~km}^{2}\right)$. These results suggest that both the population and area size - excluding the results of Budapest-Northern Great Plane has the highest average values, followed by Southern Great Plane. Turning now to the lowest results, regarding the population, it belongs to Central Transdanubia, while according to the area size, the lowest value goes to Southern Transdanubia.

Table 1. Core statistical data of the studied cities (2019).

\begin{tabular}{|c|c|c|c|c|}
\hline City & County & $\begin{array}{l}\text { Area Size of Cities } \\
\left(\mathrm{km}^{2}\right)\end{array}$ & $\begin{array}{l}\text { Population Size of Cities } \\
\text { (Number of Inhabitants) }\end{array}$ & Source \\
\hline Békéscsaba & Békés & 193.93 & 59,057 & TeIR \\
\hline Budapest & Pest & 525.14 & $1,675,370$ & TeIR \\
\hline Debrecen & Hajdú-Bihar & 461.66 & 201,081 & TeIR \\
\hline Eger & Heves & 92.21 & 51,980 & TeIR \\
\hline Győr & Győr-Moson-Sopron & 174.62 & 124,287 & TeIR \\
\hline Kaposvár & Somogy & 113.59 & 62,611 & TeIR \\
\hline Kecskemét & Bács-Kiskun & 322.57 & 110,116 & TeIR \\
\hline Miskolc & Borsod-Abaúj-Zemplén & 236.67 & 157,544 & TeIR \\
\hline Nyíregyháza & Szabolcs-Szatmár-Bereg & 274.54 & 119,765 & TeIR \\
\hline Pécs & Baranya & 162.78 & 146,721 & TeIR \\
\hline Salgótarján & Nógrád & 97.97 & 34,877 & TeIR \\
\hline Szeged & Csongrád-Csanád & 281 & 161,755 & TeIR \\
\hline Székesfehérvár & Fejér & 170.89 & 95,714 & TeIR \\
\hline Szekszárd & Tolna & 96.28 & 32,126 & TeIR \\
\hline Szolnok & Jász-Nagykun-Szolnok & 187.24 & 69,643 & TeIR \\
\hline Szombathely & Vas & 97.5 & 76,085 & TeIR \\
\hline Tatabánya & Komárom-Esztergom & 91.42 & 68,140 & TeIR \\
\hline Veszprém & Veszprém & 126.92 & 55,247 & TeIR \\
\hline Zalaegerszeg & Zala & 102.46 & 56,959 & TeIR \\
\hline Békéscsaba & Békés & 193.93 & 59,057 & TeIR \\
\hline
\end{tabular}

The selected methodology for assessing the urban sustainability of Hungarian county seats is based on available statistical indicators. Apart from the indicator selector, the classification of the variables has a pivotal role because several criteria need to be met, such as comprehensiveness, representativeness, data availability, independence, and policy relevance [41]. The main goal regarding the indicator selection process was to compile a set of indicators that can represent sustainability aspects as widely as possible, thus obtaining a nearly realistic picture of the level of sustainability of the county capitals in Hungary. In the assessment of sustainable development, the use of quantitative, i.e., measurable indicators, has proved to be more common than qualitative indicators because they allow a more accurate comparison [42-44]. Although urban sustainability is a broad concept, it is critical to tailor our research by considering local requirements and opportunities, for 
which a unique weighting technique adapted to the needs of the local community can contribute. Above all, creating a suitable set of indicators is essential; therefore, the indicators assigned to each dimension seek to cover the so-called broad sustainability concept. In the economic dimension, the indicators reflect the local economy's competitiveness to demonstrate the cities' economic dynamism, which can be described by various sub-areas, for example, economic activity, local tourism, business sector, building industry, and job opportunities for fresh graduates. In the present study, the social indicators designated measure the livability of the urban environment, in which it is crucial providing a stable family background for children, having a safe and crime-free environment, increasing the attraction of the city, having the opportunity for quality programs to spend free time, providing adequate health infrastructure, and strengthening young social strata whose members can actively represent social needs. The indicators provide information on the cities' resource management in the environmental dimension, including land use, water consumption, and waste management. They assess public awareness through the amount of waste collected selectively, the scale of public transport use, and energy consumption. In a sustainable urban environment, it is also vital to have a sufficient scale of green and recreation areas and the availability of bicycle paths to reduce environmental damage. As can be observed from the presentation of the sustainability topics, a great quantity of data can be generated; however, due to a shortage of data and the correlation analysis employed to meet the sustainability standards, the set of indicators in this study reached its limit of 30 indicators.

The raw data were obtained by using the Hungarian Central Statistical Office (KSH) and the National Spatial Development and Spatial Planning Information System (TeIR). Within TeIR, the focus was on the Interactive Analyzer and Situation-Space-Image applications. Regarding KSH, the Information Database and the Territorial Atlas Interactive Map were essential elements of the evaluation procedure. In some cases, the data was obtained from other sources, such as the price per square meter of the properties sold, which values were gathered from the ingatlannet.hu website, whereas the data of the annual proportion of days above the limit value of $\mathrm{NO}_{2}$ was retrieved from the Hungarian Meteorological Service (OMSZ). The study presents 30 sustainability indicators, 10-10 values from each dimension, namely economic, social, and environmental, seen in Table 2. The indicators applied are available, specific, reliable, and representative in the case of the Hungarian cities, meaning they are context-specific, thereby proving their appropriateness. Territorial sustainability studies appear to be a literature gap in the Hungarian context; hence, there was no adequate reference base for the indicator selection process. Due to the lack of a mature group of sustainability indicators and the relevance of validating local factors in sustainability analyses, it is possible to construct a unique indicator system that considers local characteristics. As it was previously mentioned, this topic is a gap in the Hungarian context; however, KSH has been publishing indicators of sustainable development every two years, which, although they aimed at analyzing Hungary's progress at the national level, can guide the selection of indicators. The indicators of the economic dimension reveal the relative quality of the components that make up the local economy, such as the business environment and labor market. The social dimension indicators cover a wide range of topics, such as health, safety, and family background. In the case of the environmental dimension, the indicators provide information on the resource management and land use of the county capitals and give information about the extent of the more conscious, environmentally friendly transport options and utilization. The final set of indicators was selected considering the fulfillment of the characteristics of sustainability indicators, the city-level data shortages, the need for local characteristics, and the possibility of generalizing the indices. Because the study aimed at revealing the sustainability levels of the county capitals, it was crucial to select indicators that cover a wide range of sustainability. Thus, correlation analysis has been performed at this stage to identify the possible co-movement between the chosen variables. The findings let us conclude that there were no significant 
correlations between the indicators, and thus the database was adequate to perform the comprehensive sustainability-related analysis.

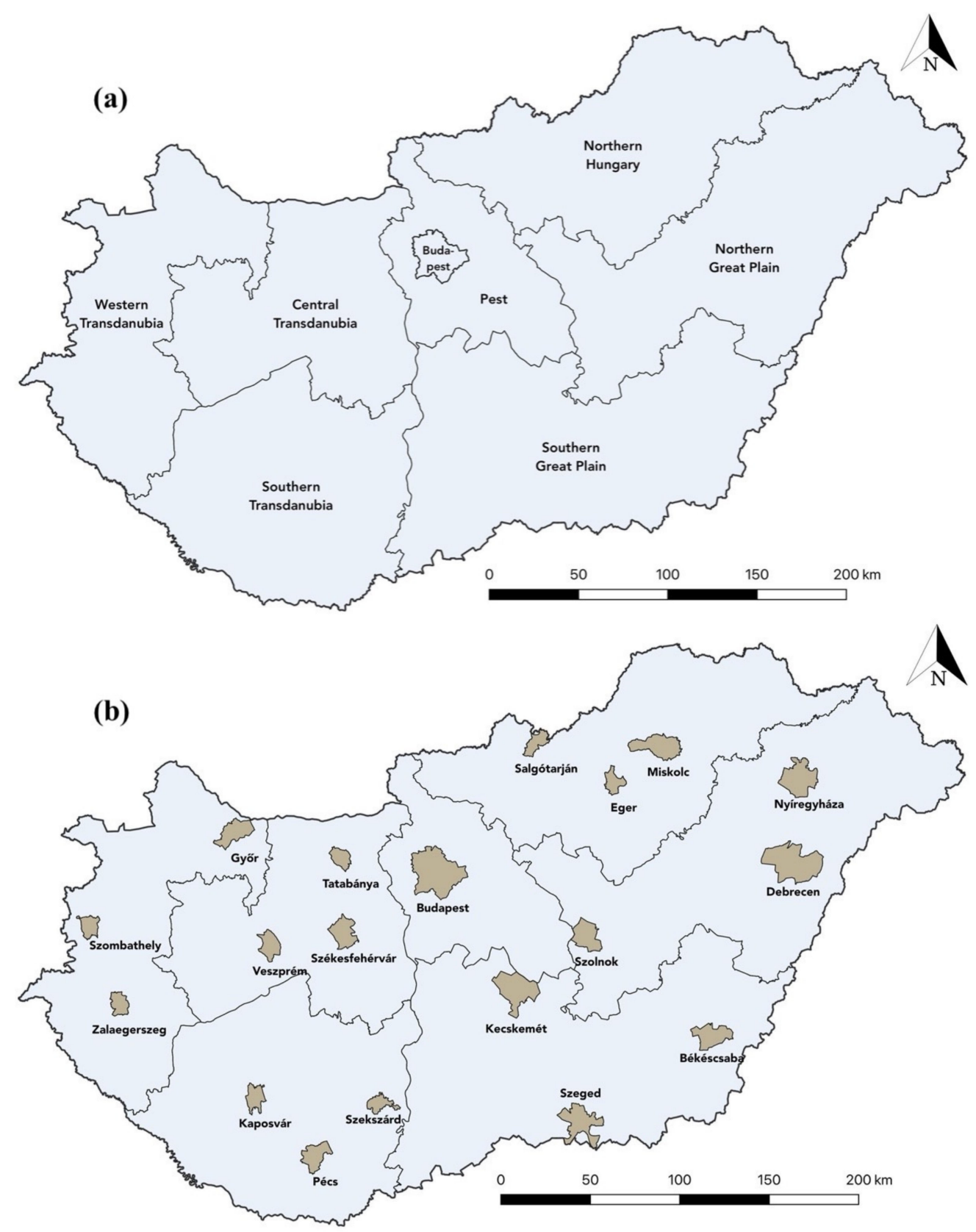

Figure 1. Study area. (a) NUTS-2 regions in Hungary; (b) the county seats of Hungary.

Due to the different units of measurement of the appointed indicators, e.g., the "number of cultural events per 1000 capita" and "amount of waste per capita", normalization of data has become necessary and unquestionable. Applying min-max methodology, the indicators were ranged from 0 to 1 , meaning the lowest result was 0 , and the highest was 1 . If the lower value has a positive meaning, such as the amount of waste per capita, the inverse of the normalized values was considered in the sustainability analysis. The normative evaluation framework presented previously has an important role even in the simplest statistical preparation. 
Table 2. Selected indicators to assess urban sustainability of Hungarian county seats.

\begin{tabular}{|c|c|c|c|c|c|}
\hline Economy & Source & Society & Source & Environment & Source \\
\hline $\begin{array}{l}\text { Number of taxpayers per } \\
1000 \text { capita }\end{array}$ & KSH & Aging indicator & TeIR & $\begin{array}{l}\text { Scale of green areas } \\
\text { per capita }\end{array}$ & TeIR \\
\hline $\begin{array}{l}\text { Long-term unemployment } \\
\text { rate }\end{array}$ & TeIR & Migration balance & TeIR & $\begin{array}{l}\text { Annual proportion } \\
\text { of days above the } \\
\text { limit value of } \mathrm{NO}_{2}\end{array}$ & OMSZ \\
\hline $\begin{array}{l}\text { Unemployment rate of } \\
\text { new entrants }\end{array}$ & TeIR & $\begin{array}{c}\text { Number of deaths per } \\
1000 \text { capita }\end{array}$ & KSH & $\begin{array}{l}\text { Water consumption } \\
\text { per capita }\end{array}$ & KSH \\
\hline $\begin{array}{l}\text { Retired entrepreneur per } \\
1000 \text { retirees }\end{array}$ & TeIR & $\begin{array}{l}\text { Number of divorces } \\
\text { per } 1000 \text { capita }\end{array}$ & TeIR & $\begin{array}{l}\text { Energy consumption } \\
\text { per capita }\end{array}$ & TeIR \\
\hline $\begin{array}{l}\text { Number of operating } \\
\text { enterprises per } 1000 \text { capita }\end{array}$ & KSH & $\begin{array}{l}\text { Number of abortions } \\
\text { per } 1000 \text { capita }\end{array}$ & TeIR & $\begin{array}{l}\text { Area of playgrounds, } \\
\text { gymnasiums, rest } \\
\text { areas per capita }\end{array}$ & TeIR \\
\hline $\begin{array}{l}\text { Proportion of professional } \\
\text { and scientific enterprises } \\
\text { within operating } \\
\text { enterprises per } 1000 \text { capita }\end{array}$ & TeIR & $\begin{array}{l}\text { Number of crimes per } \\
1000 \text { capita }\end{array}$ & KSH & $\begin{array}{l}\text { Proportion of bicycle } \\
\text { paths }\end{array}$ & TeIR \\
\hline $\begin{array}{l}\text { Number of retail stores } \\
\text { per } 10,000 \text { capita }\end{array}$ & KSH & $\begin{array}{l}\text { Number of GPs and } \\
\text { pediatricians per } 1000 \\
\text { capita }\end{array}$ & TeIR & $\begin{array}{l}\text { Proportion of waste } \\
\text { collected selectively }\end{array}$ & KSH \\
\hline $\begin{array}{l}\text { Number of guest nights } \\
\text { per } 1000 \text { capita }\end{array}$ & KSH & $\begin{array}{l}\text { Number of internet } \\
\text { subscriptions per } \\
\text { apartment }\end{array}$ & TeIR & $\begin{array}{l}\text { Amount of waste per } \\
\text { capita }\end{array}$ & KSH \\
\hline $\begin{array}{l}\text { Proportion of newly built } \\
\text { housing stock }\end{array}$ & TeIR & $\begin{array}{c}\text { Price per square meter } \\
\text { of the residential real } \\
\text { estate sold }\end{array}$ & ingatlannet.hu & $\begin{array}{l}\text { Number of } \\
\text { passengers } \\
\text { transported in public } \\
\text { transport correlate to } \\
\text { the permanent } \\
\text { population }\end{array}$ & TeIR \\
\hline PIT basic income & KSH & $\begin{array}{l}\text { Number of cultural } \\
\text { events per } 1000 \text { capita }\end{array}$ & TeIR & Road load & TeIR \\
\hline
\end{tabular}

The present study analyzed the Integrated Settlement Development Strategy (ITS) of county capitals, which the latest version defines the urban development visions and goals of the settlements for the period 2014-2020. Thus, the paper covers the base years of 2014 and 2018-2019. As the data of 2020-indicating the end of the planning period-is not yet available, the aim was to perform the research with as up-to-date data as possible. Thus, the study presents the values of 2018 or 2019, depending on their availability. ITS is a medium-term strategy reviewed by the city council at the local government at least every four years and decides whether to continue implementing the current strategy, modifying it, or creating a new one. ITS has several chapters, such as medium-term objectives and their relations, implementation interventions, strategic implementation risks, and their methods and follow-up (Government Decree 314/2012, 8 November). The data set of the base years was processed separately, and a comparative analysis was also performed for the county seats of Hungary. As elaborating weighting methodology regarding selected indicators is one of the cornerstones of the methodological solutions of the different studies aimed at the analysis of urban sustainability $[8,39,45]$, the SBTM weighting approach was determined based on the aim structure of the ITSs of the selected cities (Figure 2). The columns marked with different colors at the county seats indicate the weighted scores of the dimensions, as demonstrated by the legend. Although indicators were not given their weight; however, the sustainability dimensions were given distinguished roles and dedicated weights. For determining the exact values of the weights, medium-term strategic objectives in the urban development documents were examined in the light of the proportion of economic, social, and environmental objectives and ultimately assigned to each dimension. Thus, the generated weights do not strengthen the normative commitment of the authors, but, in each case, reflect the value judgment of a given city, thus reducing the subjective authorial 
character of this sustainability analysis. Long-term objectives were overly limited in terms of both number and description, while the methodology for designing short-term actions was exceedingly diversified; thus, medium-term thematic objectives were applied in order to determine the weights of the sustainability dimensions. Illustrated by a concrete example, in the ITS of Győr, a total of 18 medium-term goals were defined, of which three belong to the social, 4 to the economic, and 11 to the environmental dimension. The 3 goals mean $17 \%$, the 4 goals represent $22 \%$, and the 11 goals stand for $61 \%$ share, and thus the weights are 0.17 (social dimension), 0.22 (economic dimension), and 0.61 (environmental dimension). The applied weighting methodology's suitability is supported by the fact that the ITS in each case is voted and adopted by the city council, which members stand for the interests of those who delegate them, and thus the citizens are involved in the decision-making process.

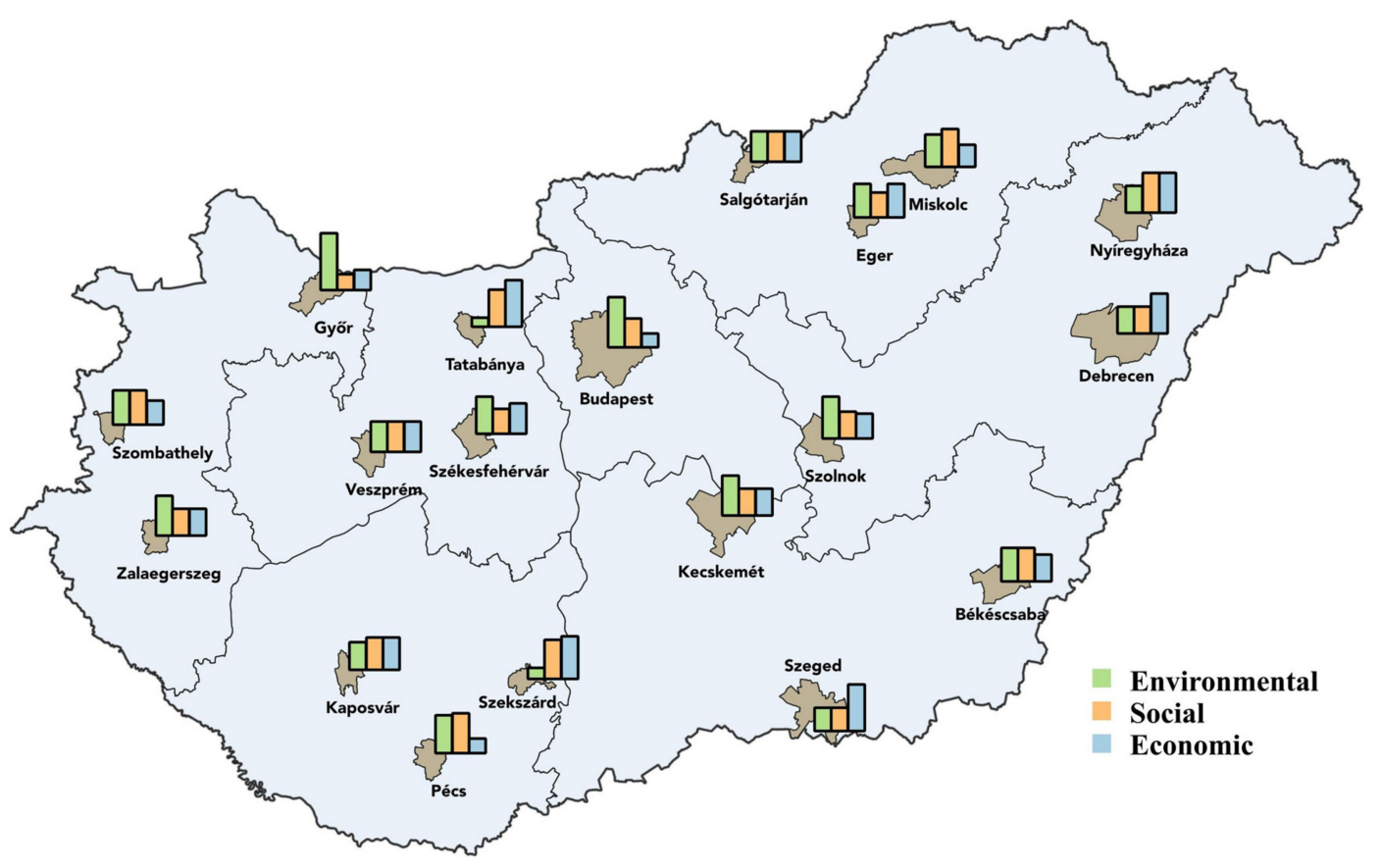

Figure 2. Dimension weights.

Because most of the data sources for each indicator were the data provider platforms under the aegis of the $\mathrm{KSH}$, the professional validity of the indicators is given by the data owner. Considering the size constraints, in the main text of the study, the average sustainability results-belonging to the Hungarian county capitals-were presented and grouped according to each dimension, calculated with the data. The average results presented in the next chapter, grouped as sustainability dimensions, were obtained by simple averaging and multiplied by the weights. As the aim of the study is the statistically centered evaluation of basic sustainability data, a regression analysis was used to reveal the indirect cause effects among the overall sustainability and the three sustainability dimensions. In the analysis of the districts of Budapest applying sustainability indicators, the social and economic dimensions better defined the final sustainability result, while the environmental dimension contributed the least, which is most typical for practice-oriented studies [33]. In the present study, the Natural breaks (Jenks) method of the QGIS software was used to create the homogeneous groups presented in the next chapter.

\section{Results}

The methodology of this study aimed at revealing the sustainability level of the Hungarian county seats and performing a regional-oriented analysis by calculating their results through the selected indicators. As it was previously introduced, indicator values 
correspond to the base years of 2014 and 2018-2019. Table 3 shows the unweighted values for 2014 and 2018-2019, thereby showing the extent and direction of the change in each city. The last two columns refer to the overall sustainability values of each city-meaning the combined value of the environmental, economic, and social dimension-for 2014 and 2018-2019, respectively.

Table 3. Unweighted results of the Hungarian county seats-grouped by sustainability dimensions.

\begin{tabular}{|c|c|c|c|c|c|c|c|c|}
\hline \multirow{2}{*}{ City } & \multicolumn{2}{|c|}{ Environment } & \multicolumn{2}{|c|}{ Economy } & \multicolumn{2}{|c|}{ Society } & \multicolumn{2}{|c|}{ Overall } \\
\hline & 2014 & 2018/19 & 2014 & 2018/19 & 2014 & 2018/19 & 2014 & 2018/19 \\
\hline Békéscsaba & 0.50 & 0.50 & 0.41 & 0.43 & 0.46 & 0.43 & 1.36 & 1.35 \\
\hline Budapest & 0.24 & 0.28 & 0.61 & 0.66 & 0.53 & 0.56 & 1.38 & 1.51 \\
\hline Debrecen & 0.32 & 0.44 & 0.41 & 0.34 & 0.60 & 0.62 & 1.33 & 1.40 \\
\hline Eger & 0.33 & 0.35 & 0.52 & 0.51 & 0.49 & 0.45 & 1.34 & 1.31 \\
\hline Győr & 0.43 & 0.46 & 0.59 & 0.61 & 0.54 & 0.56 & 1.56 & 1.63 \\
\hline Kaposvár & 0.54 & 0.54 & 0.31 & 0.35 & 0.35 & 0.38 & 1.19 & 1.27 \\
\hline Kecskemét & 0.57 & 0.59 & 0.36 & 0.49 & 0.54 & 0.48 & 1.47 & 1.57 \\
\hline Miskolc & 0.46 & 0.51 & 0.23 & 0.27 & 0.43 & 0.45 & 1.12 & 1.23 \\
\hline Nyíregyháza & 0.55 & 0.51 & 0.42 & 0.41 & 0.47 & 0.47 & 1.44 & 1.39 \\
\hline Pécs & 0.47 & 0.52 & 0.24 & 0.26 & 0.57 & 0.54 & 1.28 & 1.32 \\
\hline Salgótarján & 0.39 & 0.37 & 0.15 & 0.21 & 0.16 & 0.14 & 0.70 & 0.73 \\
\hline Szeged & 0.38 & 0.36 & 0.40 & 0.43 & 0.69 & 0.55 & 1.47 & 1.35 \\
\hline Székesfehérvár & 0.40 & 0.45 & 0.46 & 0.46 & 0.57 & 0.53 & 1.44 & 1.44 \\
\hline Szekszárd & 0.35 & 0.37 & 0.45 & 0.47 & 0.53 & 0.45 & 1.33 & 1.29 \\
\hline Szolnok & 0.37 & 0.39 & 0.37 & 0.37 & 0.40 & 0.49 & 1.13 & 1.25 \\
\hline Szombathely & 0.39 & 0.37 & 0.39 & 0.44 & 0.59 & 0.58 & 1.37 & 1.39 \\
\hline Tatabánya & 0.45 & 0.36 & 0.24 & 0.33 & 0.50 & 0.52 & 1.19 & 1.20 \\
\hline Veszprém & 0.35 & 0.39 & 0.60 & 0.65 & 0.67 & 0.61 & 1.62 & 1.65 \\
\hline Zalaegerszeg & 0.46 & 0.50 & 0.41 & 0.38 & 0.48 & 0.51 & 1.35 & 1.39 \\
\hline
\end{tabular}

The overall sustainability values listed in Table 3 are represented in Figure 3 below to reveal regional patterns of urban sustainability. The maps were created in QGIS software using the Natural breaks (Jenks) method, as it was previously mentioned. As the legend shows, the cities, according to their sustainability results, are classified into five categories (red color-the weakest performance; darker green-strongest performance). The upper map demonstrates the results corresponding to 2014 and the lower to 2018-2019. Both maps show a strong Central Transdanubia axis, with an outstanding sustainability result of Veszprém. It is clearly represented that the cities with the weakest level of sustainability are in Southern Transdanubia and Northern Hungary. In both base years, Györ and Veszprém reached the highest level of sustainability, and Salgótarján retained its low value. Based on the average overall results, the sustainability level was approximately 1.4 in Western Transdanubia, Central Transdanubia, and Southern Great Plane, while in Southern Transdanubia, and mainly in Northern Great Plain and Northern Hungary, a weaker level was detected. In 2014, Northern Hungary did not even reach the value of 1, and regarding the base year of 2018-2019, it was only 1.09. Budapest reached a weaker level in 2014, but its result improved by 2018-2019, as shown by its category change (turning green).

Table 4 represents the weighted values for 2014 and 2018-2019, thereby showing the extent and direction of the change in each city. The weights were calculated by taking into consideration the aim structure of the ITSs of county seats, then the values from Table 3 were multiplied by them. Because the weights reflect the priorities of the listed cities-meaning they focus on the weaknesses of their city, thereby giving more emphasis to the given dimension-and affect their performance significantly, in this case, the weaker ones can show a more remarkable development. 

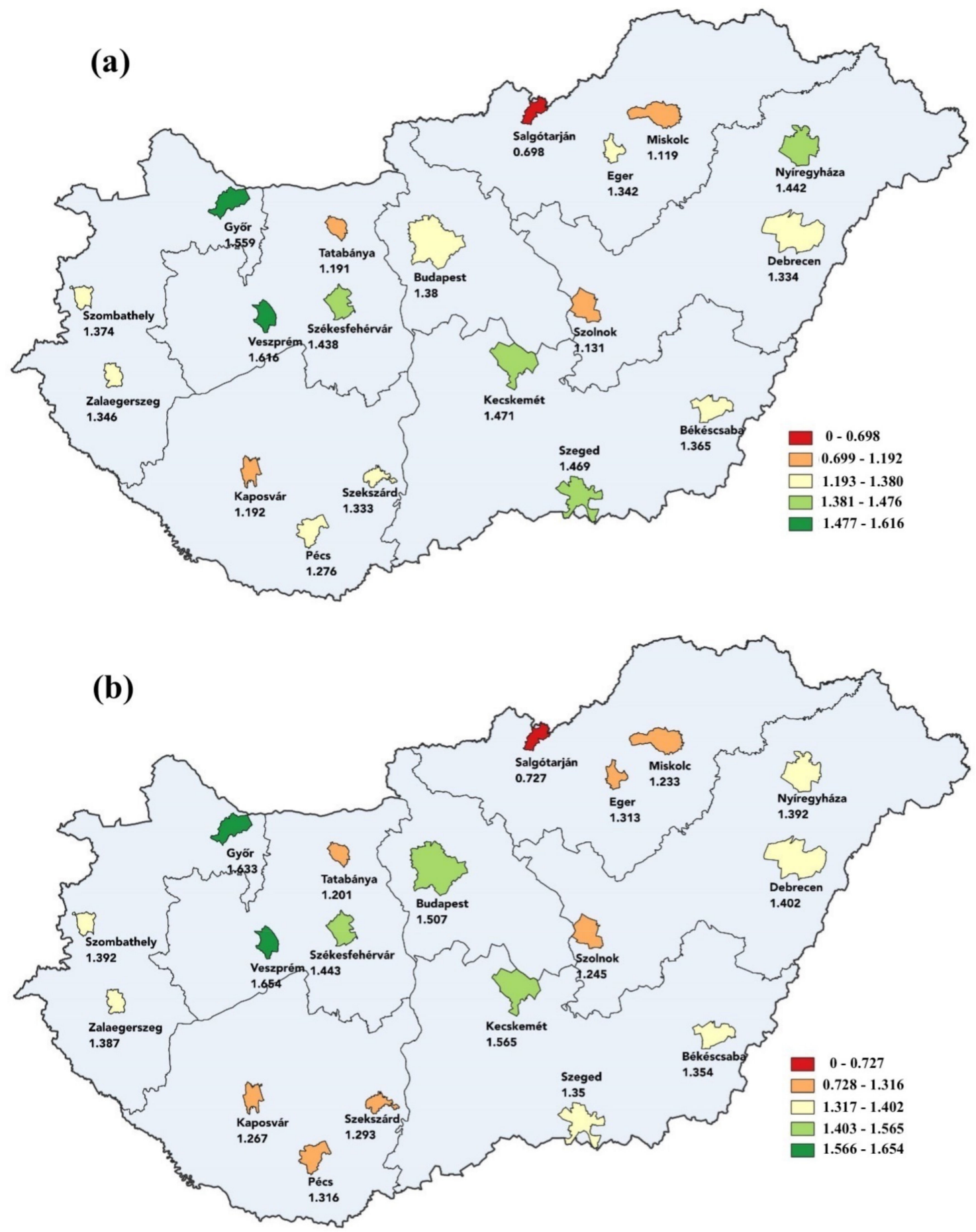

Figure 3. Overall sustainability results—unweighted values for (a) 2014, (b) 2018-2019.

The overall sustainability values are represented in Figure 4 below and the case of the unweighted results. As the legend shows here, too, the cities based on their sustainability results are classified into five main categories (red color-the weakest performance; darker green-the strongest performance), applying the Jenks natural breaks methodology. Map (a) demonstrates the results corresponding to 2014, and map (b) refers to 2018-2019. As it was mentioned before, the weights can significantly affect the performance of the cities, meaning the weaker ones can show a greater development. As the maps show, it can be stated in general that the county capitals stand for better sustainability levels. Both maps show a strong Western Transdanubia and Southern Great Plane axis; however, 
during the years Western Transdanubia region shows a greater improvement regarding Zalaegerszeg's upturn, whilst in the Southern Great Plain region, Szeged was ranked in a weaker group by the year 2018-2019. Based on the average values of the overall weighted results, all the regions show similar results around 0.4, except Northern Hungary, in which the sustainability level is weaker because it is around 0.3 according to both base years-probably because of Salgótarján because it performs very poorly, which can lower the average. Regarding the results of the base year of 2018-2019, strong west and south axes can be detected, while the regions in the north and central fall behind the others.

Table 4. Weighted results of the Hungarian county seats grouped by sustainability dimensions.

\begin{tabular}{|c|c|c|c|c|c|c|c|c|}
\hline \multirow{2}{*}{ City } & \multicolumn{2}{|c|}{ Environment } & \multicolumn{2}{|c|}{ Economy } & \multicolumn{2}{|c|}{ Society } & \multicolumn{2}{|c|}{ Overall } \\
\hline & 2014 & $2018 / 19$ & 2014 & $2018 / 19$ & 2014 & $2018 / 19$ & 2014 & 2018/19 \\
\hline Békéscsaba & 0.18 & 0.18 & 0.12 & 0.12 & 0.16 & 0.15 & 0.46 & 0.46 \\
\hline Budapest & 0.13 & 0.15 & 0.09 & 0.1 & 0.17 & 0.18 & 0.39 & 0.43 \\
\hline Debrecen & 0.09 & 0.13 & 0.18 & 0.15 & 0.17 & 0.18 & 0.44 & 0.45 \\
\hline Eger & 0.12 & 0.13 & 0.19 & 0.18 & 0.13 & 0.12 & 0.44 & 0.43 \\
\hline Győr & 0.26 & 0.28 & 0.13 & 0.14 & 0.09 & 0.1 & 0.49 & 0.51 \\
\hline Kaposvár & 0.16 & 0.16 & 0.11 & 0.12 & 0.12 & 0.13 & 0.39 & 0.42 \\
\hline Kecskemét & 0.24 & 0.26 & 0.11 & 0.14 & 0.16 & 0.14 & 0.51 & 0.54 \\
\hline Miskolc & 0.16 & 0.18 & 0.06 & 0.06 & 0.18 & 0.19 & 0.39 & 0.43 \\
\hline Nyíregyháza & 0.16 & 0.15 & 0.18 & 0.18 & 0.2 & 0.2 & 0.54 & 0.53 \\
\hline Pécs & 0.19 & 0.21 & 0.04 & 0.04 & 0.24 & 0.23 & 0.47 & 0.49 \\
\hline Salgótarján & 0.13 & 0.12 & 0.05 & 0.07 & 0.05 & 0.05 & 0.23 & 0.24 \\
\hline Szeged & 0.1 & 0.09 & 0.2 & 0.22 & 0.17 & 0.14 & 0.47 & 0.45 \\
\hline Székesfehérvár & 0.16 & 0.18 & 0.15 & 0.15 & 0.15 & 0.14 & 0.47 & 0.48 \\
\hline Szekszárd & 0.04 & 0.04 & 0.21 & 0.22 & 0.22 & 0.19 & 0.47 & 0.45 \\
\hline Szolnok & 0.16 & 0.18 & 0.1 & 0.1 & 0.12 & 0.14 & 0.38 & 0.42 \\
\hline Szombathely & 0.14 & 0.14 & 0.1 & 0.11 & 0.22 & 0.22 & 0.47 & 0.47 \\
\hline Tatabánya & 0.05 & 0.04 & 0.12 & 0.16 & 0.2 & 0.21 & 0.36 & 0.41 \\
\hline Veszprém & 0.12 & 0.13 & 0.2 & 0.22 & 0.22 & 0.2 & 0.53 & 0.55 \\
\hline Zalaegerszeg & 0.2 & 0.21 & 0.12 & 0.11 & 0.14 & 0.15 & 0.45 & 0.47 \\
\hline
\end{tabular}

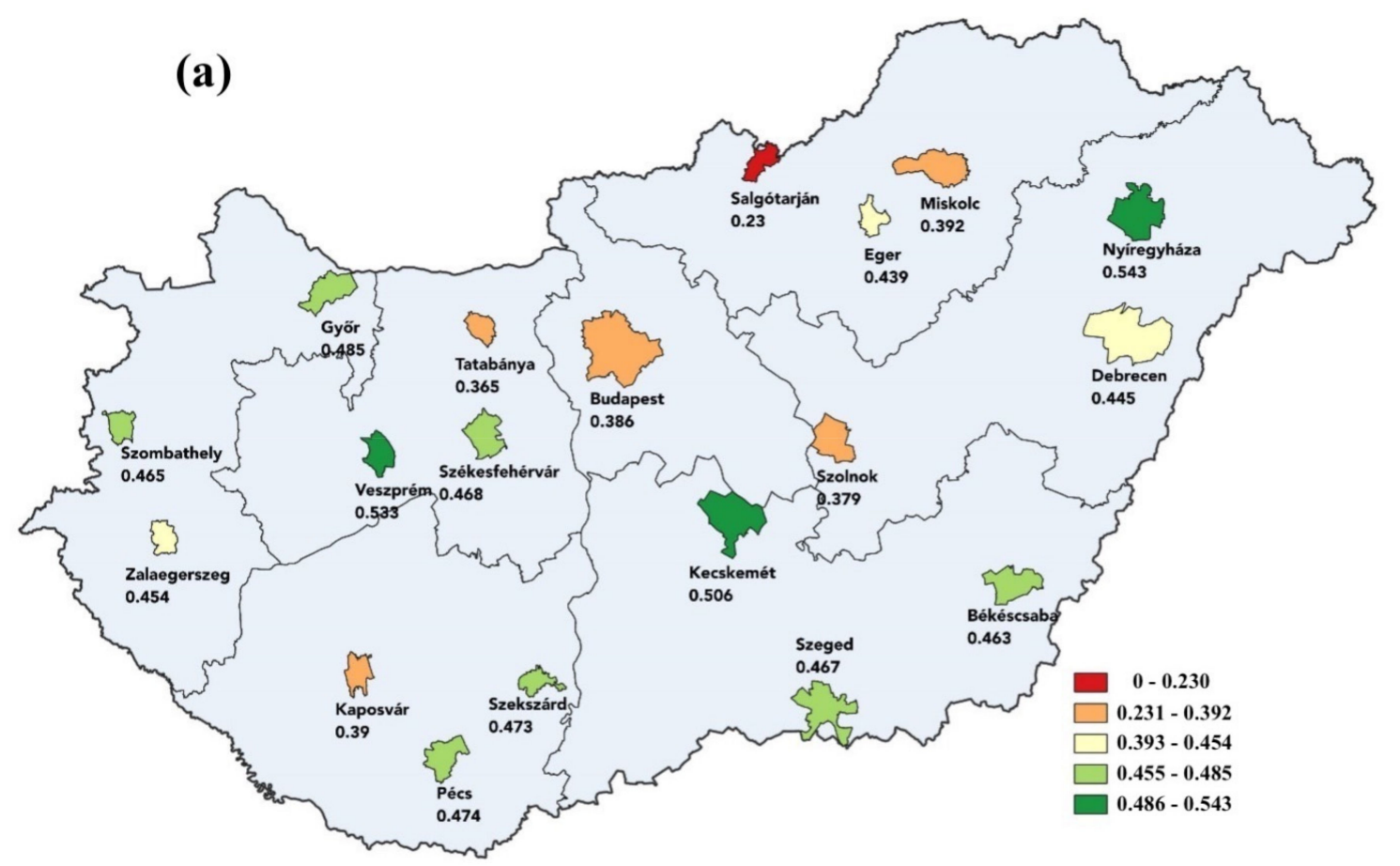

Figure 4. Cont. 


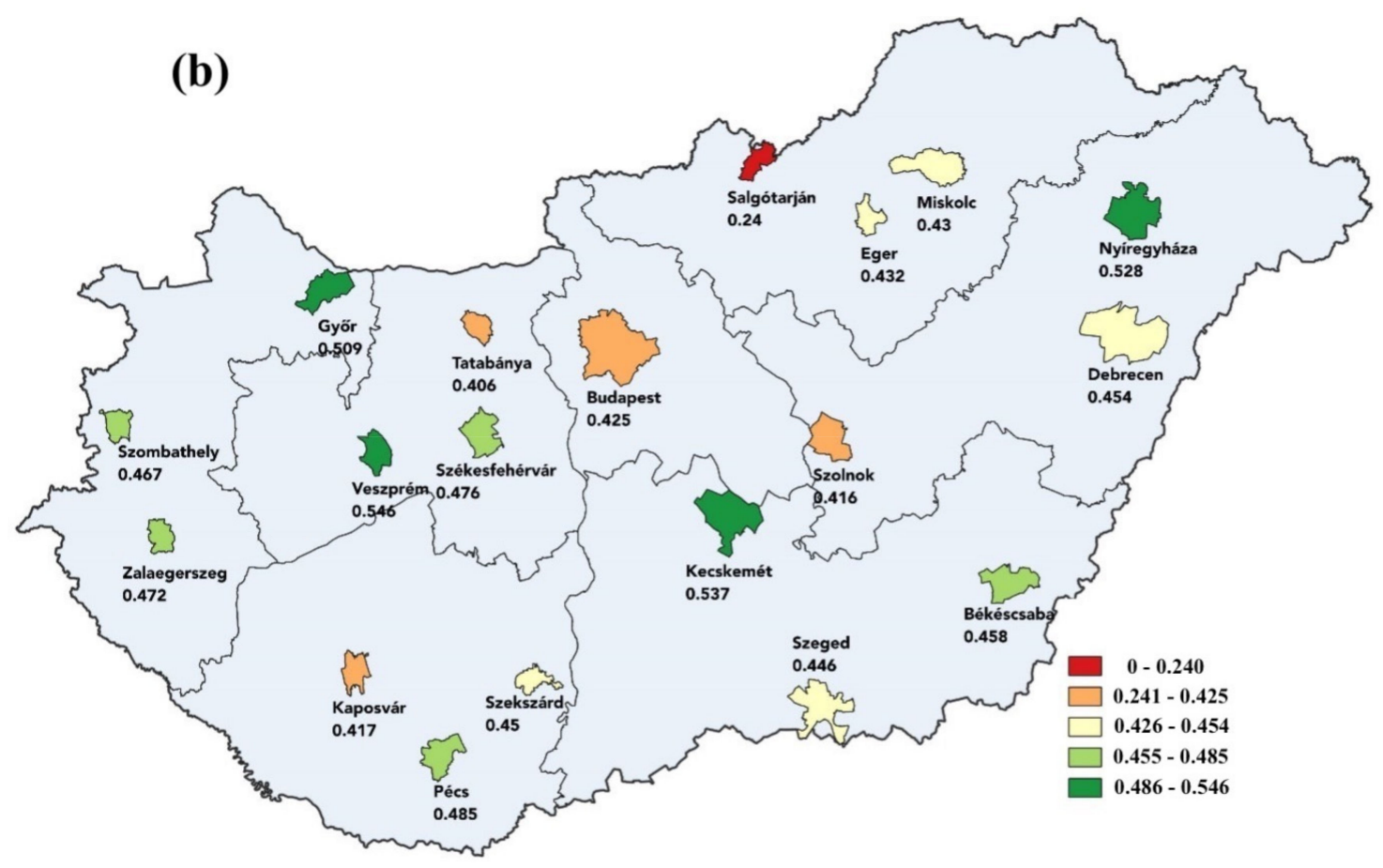

Figure 4. Overall sustainability results—weighted values for (a) 2014, (b) 2018-2019.

The study also aimed at revealing the tendency of the sustainability level of each city, meaning to analyze the change between the base years of 2014 and 2018-2019 regarding the unweighted and weighted results. Table 5 represents the values in percent, showing the extent and direction of the changes. The second column demonstrates the unweighted results, and the third one refers to the weighted outcomes. According to both the unweighted and weighted results of the change in 2014 and 2018-2019, it can be stated that in 5 cases-Békéscsaba, Eger, Nyíregyháza, Szeged, and Szekszárd-there was a decrease in the level of sustainability, while the other 14 cities improved their values; however, the extent of the development vary in each city. In the case of the unweighted results, the most considerable improvement belongs to Miskolc with an increased value of $10.21 \%$, whereas Szeged sustainability performance worsened by $8.09 \%$. Based on the weighted results, the ranking is different because immense growth is linked to Tatabánya $(11.45 \%)$, while Szekszárd's sustainability level decreased the most $(-4.86 \%)$.

Figure 5 shows the categories in which all the county capitals were classified into five different groups, regarding the extent and direction of their change during the years under review. Map (a) refers to the changes according to the unweighted sustainability levels, while map (b) representing the changes according to weighted sustainability levels. As the legend shows, the cities based on their change in their sustainability level are classified into five categories, marked with different colors from red to darker green, consequently moving towards green means improvement, i.e., the values are the cities' self-measured developments or declines. Findings can also be defined based on the average values of cities in the different regions. According to the unweighted results, the most considerable improvement belongs to Budapest $(+9.19 \%)$, which stands out from the other regions. Thus, it is recommended to analyze the other regions separately in this case. Regarding the rest, Northern Hungary $(+4.04 \%)$ and Northern Great Plain $(+3.9 \%)$ own the most significant change of sustainability level, while the weakest change was observed in Southern Great Plain $(-0.85 \%)$. Based on the weighted values, the results are similar; Budapest is still outstanding with the value of $10.35 \%$, and regarding the rest of the regions, Central Transdanubia $(+5.15 \%)$ and Northern Hungary $(+4.05 \%)$ show the greatest development. However, Southern Great Plain (+0.19) improved its value; it still falls behind the others. 
Table 5. Relative changes in the sustainability level correspond to 2014 and 2018-2019-based on unweighted and weighted results.

\begin{tabular}{ccc}
\hline & \multicolumn{2}{c}{ Change } \\
\cline { 2 - 3 } City & Unweighted & Weighted \\
\cline { 2 - 3 } & $-0.84 \%$ & $-1.16 \%$ \\
Békéscsaba & $9.19 \%$ & $10.35 \%$ \\
Budapest & $5.10 \%$ & $2.09 \%$ \\
Debrecen & $-2.18 \%$ & $-1.63 \%$ \\
Eger & $4.76 \%$ & $4.96 \%$ \\
Győr & $6.33 \%$ & $6.72 \%$ \\
Kaposvár & $6.39 \%$ & $6.13 \%$ \\
Kecskemét & $10.21 \%$ & $9.68 \%$ \\
Miskolc & $-3.45 \%$ & $-2.93 \%$ \\
Nyíregyháza & $3.09 \%$ & $2.37 \%$ \\
Pécs & $4.09 \%$ & $4.09 \%$ \\
Salgótarján & $-8.09 \%$ & $-4.40 \%$ \\
Szeged & $0.41 \%$ & $1.68 \%$ \\
Székesfehérvár & $-2.97 \%$ & $-4.86 \%$ \\
Szekszárd & $10.04 \%$ & $9.76 \%$ \\
Szolnok & $1.35 \%$ & $0.43 \%$ \\
Szombathely & $0.76 \%$ & $11.45 \%$ \\
Tatabánya & $2.33 \%$ & $2.33 \%$ \\
Veszprém & $3.07 \%$ & $3.80 \%$ \\
Zalaegerszeg & &
\end{tabular}

Finally, the regression analyses regarding dimensional and overall sustainability values were performed for 2014, 2018-2019 indices taking into consideration both weighted and unweighted results (Tables 6 and 7). According to our calculation, the $\mathrm{R}^{2}$ determination coefficient in the case of unweighted values regarding economic, social, and environmental dimensions was $0.601,0.726$, and 0.000 , respectively. Almost the same values $(0.606$, $0.666,0.030)$ were determined for the later timeframe. It can be stated that economic and social dimensions are closely related to overall sustainability; however, there was no or just a slight connection between environmental and overall indices. In other words, the determinant power of environmental sustainability to overall urban sustainability is really close—or equal—to zero; consequently, environmental performance is almost entirely independent from overall values.

Table 6. $R^{2}$ values regarding weighted sustainability.

\begin{tabular}{ccc}
\hline \multirow{2}{*}{ Dimension } & \multicolumn{2}{c}{ Overall Sustainability-Unweighted } \\
\cline { 2 - 3 } & $\mathbf{2 0 1 4}$ & $\mathbf{2 0 1 8 / 1 9}$ \\
\hline Economic & 0.601 & 0.606 \\
Social & 0.726 & 0.666 \\
Environmental & 0.000 & 0.030 \\
\hline
\end{tabular}

Table 7. $R^{2}$ values regarding weighted sustainability.

\begin{tabular}{ccc}
\hline \multirow{2}{*}{ Dimension } & \multicolumn{2}{c}{ Overall Sustainability-Weighted } \\
\cline { 2 - 3 } & $\mathbf{2 0 1 4}$ & $\mathbf{2 0 1 8 / 1 9}$ \\
\hline Economic & 0.308 & 0.139 \\
Social & 0.337 & 0.265 \\
Environmental & 0.062 & 0.148 \\
\hline
\end{tabular}

The same calculations were performed for the weighted results, but the outcome is slightly different. Firstly, take a look at the 2014 results: 0.308, 0.337, 0.062. According to these values, the overrepresentation of economic and social dimensions is still valid; 
however, the 2018-2019 values depict another situation with 0.139, 0.265, and 0.148. Based on the latter outcomes, it can be concluded that the environmental aspects are more emphasized if decision makers' perceptions are considered.
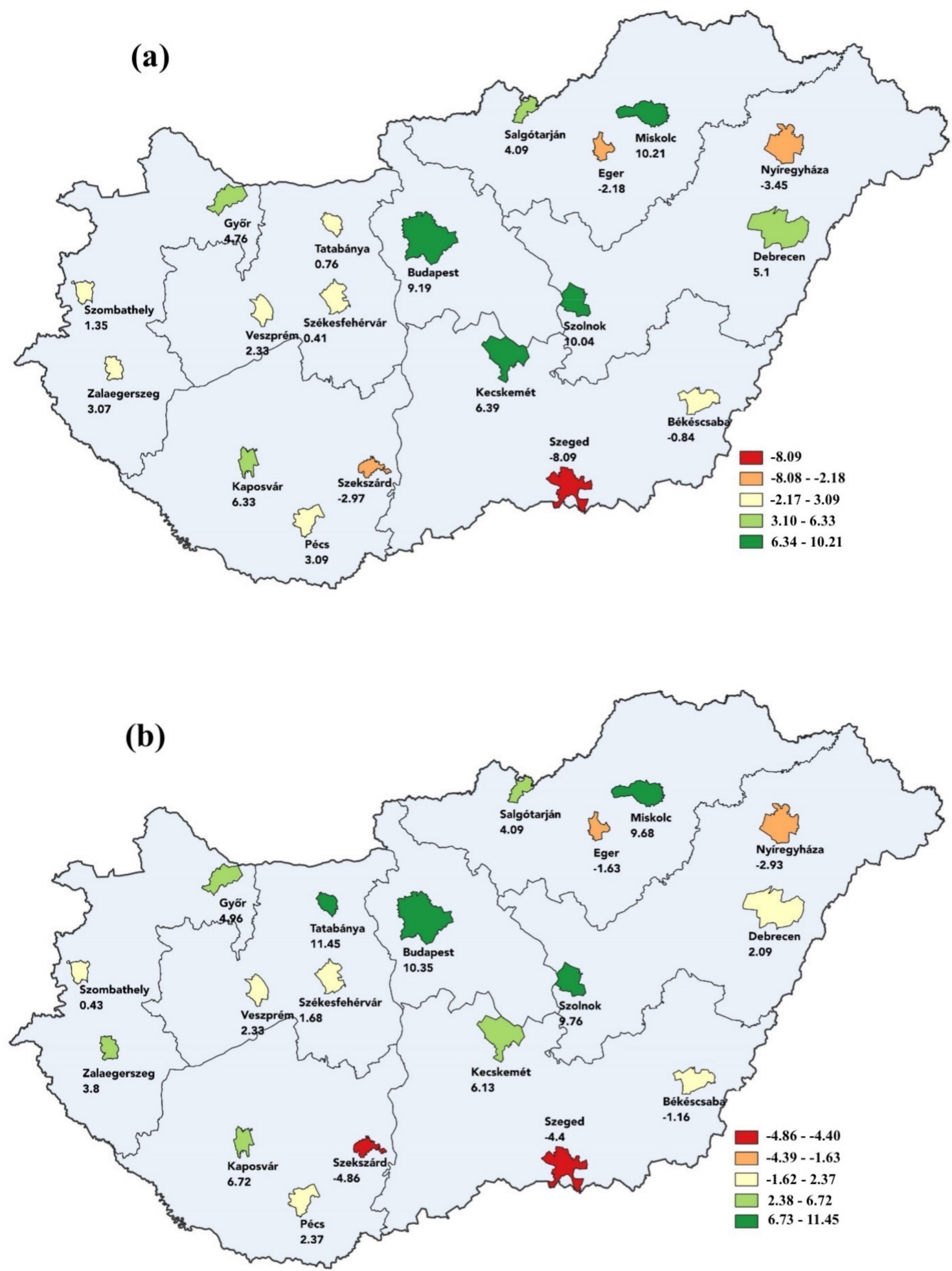

Figure 5. Changes in the sustainability level correspond to 2014 and 2018-2019-based on unweighted (a) and weighted (b) results. 


\section{Discussion}

This study aimed to assess the spatiotemporal urban sustainability pattern in the Hungarian county seats by applying the SBTM weighting methodology and indicator method. The main novelty of the present paper can be grasped through the rarely studied Hungarian context, the wide range of sustainability aspects covered by the almost fully independent indicators, and the applied weighting methodology. As introduced before, comparative analysis of Hungarian cities cannot be available yet; however, international literature is quite rich from this perspective. Although the applied methodology and findings contribute to revealing spatiotemporal patterns of sustainability regarding the selected cities, three main limitations might be emphasized in the following:

- firstly, the indicator selection process is always a crucial point of sustainability analyses. In this study, 30 indicators have been involved, paying attention to a wide range of urban sustainability, proven by correlation analysis. Although the selected variables are closely related to universal sustainability dimensions, such as economic, social and environmental aspects, they reflect the Hungarian urban context. In this matter, selected indicators are context-specific based on their availability; however, generalization is feasible because the covered sustainability aspects and challenges are quite similar in the developed world, especially in the Central-Eastern European region. Because the indicator collection process was based on data availability, using the database of the Central Statistical Office, the analysis can be expanded to other municipalities in Hungary.

- Secondly, the applied SBTM weighting methodology refers to the perception of different urban planners and decision-makers through identifying the weights from the emphases of urban development strategies. Selecting weighting methodology is always a subjective process, although the widely accepted and applied methods try to reduce this subjectivity by using mathematical solutions to define weights. Nevertheless, in this study, a tailor-made weighting process was elaborated and selected to reveal the most relevant sustainability issues regarding each selected city without overrepresenting any aspects. According to the Government Decree 314/2012 (8 November), developing an Integrated Settlement Development Strategy is compulsory at the urban level; consequently, this analysis can be repeated in every Hungarian city based on the structure of the medium-term goals of their development strategies.

- Finally, composite indices concerning such a complex issue as urban sustainability often hide the microscale aspects behind the overall value. Furthermore, city-scale assessments cannot be applied to distinguish complicated socioeconomic and environmental indicators. Nevertheless, the comparative analysis conducted in this study was devoted to defining the main spatiotemporal differences regarding selected Hungarian studies by providing insight about comprehensive sustainability issues. However, further analysis might pay attention to district-scale evaluation, although, data availability of socioeconomic valuables for Hungarian cities (except Budapest) is limited from this analysis perspective.

Besides the hereby distinguished and listed limitations, this study contributes to widening the existing literature by analyzing a rarely studied area and providing a tailormade, still-generalizable methodology. The selected indicators are context-specific; however, numerous studies can be found in the literature, studies that use a divergent set of variables to define urban sustainability comparisons. The SBTM weighting methodology can be uniformized as well: the local context can be transferred to the analysis through the detailed assessment of urban development goals and visions. Therefore, the presented methodology can easily be adapted to other urban areas; consequently, practice-related opportunities and further application might be realized. Comparing the normalized only (i.e., unweighted) and the weighted approach reveals interesting findings and emphasizes the importance of using this method. The results obtained employing the dimension weights determined by the SBTM method highlight the criteria of the cities; hence the outcomes may differ slightly from the unweighted version; however, because ITS is a sustainability- 
focused strategy itself, a significant difference is unlikely. The weights assigned to each dimension also reflect the importance level of the dimensions in terms of the need for development. If a relative improvement is observed at a lower-performing county seat, then the weaker dimensions have been correctly marked, as more weight has been assigned to them, so they also more important, hence increasing the city's sustainability result.

\section{Conclusions}

The present paper aimed to assess the urban sustainability of Hungarian county seats and to reveal regional patterns regarding overall results by performing a comparative analysis. The applied methodology is based on available statistical indicators to reflect social, economic, and environmental aspects. Altogether 30 indicators were used to perform the analyses, covering a broad spectrum of urban sustainability by applying independent variables was proved by correlation analysis. The elaborated weighting technology is unique compared to current approaches because it reflects decision makers' and urban planners' perceptions about urban sustainability in a given city by analyzing the aim structure of the urban development plans. Thus, a strategy-based tailor-made (SBTM) weighting methodology made sure to take into consideration the different emphases regarding local aspects and main issues of sustainability. The results were calculated by using data from 2014 and 2018-2019 based on the current planning timeframes and data availability. After analyzing the outcomes, it can be stated that the east-west axis was revealed regarding weighted and unweighted results; however, some exceptions can be found, which slightly modifies the before-mentioned regional pattern. Concerning the relative changes in urban sustainability performance, a highly heterogeneous spatial pattern can be drawn without clearly defined regional clusters. It can be concluded that unequivocal and easily detected regional patterns cannot be defined regarding urban sustainability values of Hungarian county seats; consequently, the overall performance highly depends on local patterns and does not follow regional rules and similarities. Finally, the regression analysis revealed the relative importance of sustainability dimensions in terms of overall urban sustainability. According to the results, it can be stated that environmental aspects are more emphasized if the decision makers' perceptions have been taken into consideration by looking at the weighted values. This paper contributes to widening the literature in two ways: firstly, a rarely studied area was in the center of the analyses; secondly, the elaborated weighting method is unique and reflects local perceptions about sustainability; however, it can be easily transformable and adaptable to other case studies.

Author Contributions: Conceptualization, A.B.; methodology, A.B. and B.S.J.; investigation, A.B. and B.S.J.; data curation, B.S.J.; writing-original draft preparation, A.B. and B.S.J.; visualization, A.B.; supervision, A.B. All authors have read and agreed to the published version of the manuscript.

Funding: This research received no external funding.

Institutional Review Board Statement: Not applicable.

Informed Consent Statement: Not applicable.

Conflicts of Interest: The authors declare no conflict of interest.

\section{References}

1. Ali-Toudert, F.; Ji, L. Modeling and measuring urban sustainability in multi-criteria based systems-A challenging issue. Ecol. Indic. 2017, 73, 597-611. [CrossRef]

2. Durrant, R.; Barnes, J.; Kern, F.; Mackerron, G. The acceleration of transitions to urban sustainability: A case study of Brighton and Hove. Eur. Plan. Stud. 2018, 26, 1537-1558. [CrossRef]

3. Elmqvist, T.; Andersson, E.; Frantzeskaki, N.; McPhearson, T.; Olsson, P.; Gaffney, O.; Takeuchi, K.; Folke, C. Sustainability and resilience for transformation in the urban century. Nat. Sustain. 2019, 2, 267-273. [CrossRef]

4. Akande, A.; Cabral, P.; Gomes, P.; Casteleyn, S. The Lisbon ranking for smart sustainable cities in Europe. Sustain. Cities Soc. 2019, 44, 475-487. [CrossRef] 
5. Petit-Boix, A.; Llorach-Massana, P.; Sanjuan-Delmás, D.; Sierra-Pérez, J.; Vinyes, E.; Gabarrell, X.; Rieradevall, J.; Sanyé-Mengual, E. Application of life cycle thinking towards sustainable cities: A review. J. Clean. Prod. 2017, 166, 939-951. [CrossRef]

6. Yigitcanlar, T.; Dur, F.; Dizdaroglu, D. Towards prosperous sustainable cities: A multiscalar urban sustainability assessment approach. Habitat Int. 2015, 45, 36-46. [CrossRef]

7. Cohen, M. A systematic review of urban sustainability assessment literature. Sustainability 2017, 9, 2048. [CrossRef]

8. Verma, P.; Raghubanshi, A.S. Urban sustainability indicators: Challenges and opportunities. Ecol. Indic. 2018, 93, 282-291. [CrossRef]

9. Albrechts, L.; Barbanente, A.; Monno, V. Practicing transformative planning: The territory-landscape plan as a catalyst for change. City Territ. Archit. 2020, 7, 1-13. [CrossRef]

10. Ehnert, F.; Frantzeskaki, N.; Barnes, J.; Borgström, S.; Gorissen, L.; Kern, F.; Strenchock, L.; Egermann, M. The acceleration of urban sustainability transitions: A comparison of Brighton, Budapest, Dresden, Genk, and Stockholm. Sustainability 2018, 10, 612. [CrossRef]

11. Deng, D.; Liu, S.; Wallis, L.; Duncan, E.; McManus, P. Urban Sustainability Indicators: How do Australian city decision makers perceive and use global reporting standards? Aust. Geogr. 2017, 48, 401-416. [CrossRef]

12. Steiniger, S.; Wagemann, E.; de la Barrera, F.; Molinos-Senante, M.; Villegas, R.; de la Fuente, H.; Vives, A.; Arce, G.; Herrera, J.C.; Carrasco, J.A.; et al. Localising urban sustainability indicators: The CEDEUS indicator set, and lessons from an expert-driven process. Cities 2020, 101, 102683. [CrossRef]

13. Huang, L.; Yan, L.; Wu, J. Assessing urban sustainability of Chinese megacities: 35 years after the economic reform and open-door policy. Landsc. Urban Plan. 2016, 145, 57-70. [CrossRef]

14. Michael, F.L.; Noor, Z.Z.; Figueroa, M.J. Review of urban sustainability indicators assessment-Case study between Asian countries. Habitat Int. 2014, 44, 491-500. [CrossRef]

15. Regmi, M.B. Measuring sustainability of urban mobility: A pilot study of Asian cities. Case Stud. Transp. Policy 2020, 8, 1224-1232. [CrossRef]

16. Cortinovis, C.; Haase, D.; Zanon, B.; Geneletti, D. Is urban spatial development on the right track? Comparing strategies and trends in the European Union. Landsc. Urban Plan. 2019, 181, 22-37. [CrossRef]

17. Gonzalez-Garcia, S.; Manteiga, R.; Moreira, M.T.; Feijoo, G. Assessing the sustainability of Spanish cities considering environmental and socio-economic indicators. J. Clean. Prod. 2018, 178, 599-610. [CrossRef]

18. Sartison, K.; Artmann, M. Edible cities-An innovative nature-based solution for urban sustainability transformation? An explorative study of urban food production in German cities. Urban For. Urban Green. 2020, 49, 126604. [CrossRef]

19. Altamirano-Avila, A.; Martínez, M. Urban sustainability assessment of five Latin American cities by using SDEWES index. J. Clean. Prod. 2021, 287, 125495. [CrossRef]

20. Currie, P.K.; Musango, J.K. African Urbanization: Assimilating Urban Metabolism into Sustainability Discourse and Practice. J. Ind. Ecol. 2017, 21, 1262-1276. [CrossRef]

21. Nagendra, H.; Bai, X.; Brondizio, E.S.; Lwasa, S. The urban south and the predicament of global sustainability. Nat. Sustain. 2018, 1,341-349. [CrossRef]

22. Xu, G.; Dong, T.; Cobbinah, P.B.; Jiao, L.; Sumari, N.S.; Chai, B.; Liu, Y. Urban expansion and form changes across African cities with a global outlook: Spatiotemporal analysis of urban land densities. J. Clean. Prod. 2019, 224, 802-810. [CrossRef]

23. Duinker, P.N.; Ordóñez, C.; Steenberg, J.W.N.; Miller, K.H.; Toni, S.A.; Nitoslawski, S.A. Trees in canadian cities: Indispensable life form for urban sustainability. Sustainability 2015, 7, 7379-7396. [CrossRef]

24. Opp, S.M. The forgotten pillar: A definition for the measurement of social sustainability in American cities. Local Environ. 2017, 22, 286-305. [CrossRef]

25. Opp, S.M.; Saunders, K.L. Pillar Talk: Local Sustainability Initiatives and Policies in the United States-Finding Evidence of the "Three E's": Economic Development, Environmental Protection, and Social Equity. Urban Aff. Rev. 2013, 49, 678-717. [CrossRef]

26. $\mathrm{Hu}, \mathrm{R}$. Sustainability and competitiveness in Australian cities. Sustainability 2015, 7, 1840-1860. [CrossRef]

27. Thornton, A. "The Lucky country"? A critical exploration of community gardens and city-community relations in Australian cities. Local Environ. 2017, 22, 969-985. [CrossRef]

28. Kiss, V.M. Modelling the energy system of Pécs-The first step towards a sustainable city. Energy 2015, 80, 373-387. [CrossRef]

29. Sebestyén, V.; Somogyi, V.; Szőke, S.; Utasi, A. Adapting the SDEWES Index to Two Hungarian Cities. Hungarian J. Ind. Chem. 2018, 45, 49-59. [CrossRef]

30. Lux, G. Minor Cities in a Metropolitan World: Challenges for Development and Governance in Three Hungarian Urban Agglomerations. Int. Plan. Stud. 2015, 20, 21-38. [CrossRef]

31. Bajmócy, Z.; Gébert, J.; Málovics, G.; Berki, B.M.; Juhász, J. Urban Strategic Planning from the Perspective of Well-Being: Evaluation of the Hungarian Practice. Eur. Spat. Res. Policy 2020, 27, 221-241. [CrossRef]

32. Kovács, Z.; Farkas, Z.J.; Egedy, T.; Kondor, A.C.; Szabó, B.; Lennert, J.; Baka, D.; Kohán, B. Urban sprawl and land conversion in post-socialist cities: The case of metropolitan Budapest. Cities 2019, 92, 71-81. [CrossRef]

33. Buzási, A.; Jäger, B.S. District-scale assessment of urban sustainability. Sustain. Cities Soc. 2020, 62, 102388. [CrossRef]

34. Corredor-Ochoa, Á.; Antuña-Rozado, C.; Fariña-Tojo, J.; Rajaniemi, J. Challenges in assessing urban sustainability. Urban Ecol. 2020, 355-374. [CrossRef] 
35. Ahvenniemi, H.; Huovila, A.; Pinto-Seppä, I.; Airaksinen, M. What are the differences between sustainable and smart cities? Cities 2017, 60, 234-245. [CrossRef]

36. Feleki, E.; Vlachokostas, C.; Moussiopoulos, N. Characterisation of sustainability in urban areas: An analysis of assessment tools with emphasis on European cities. Sustain. Cities Soc. 2018, 43, 563-577. [CrossRef]

37. Gouda, A.A.; Masoumi, H.E. Certifications systems as independent and rigorous tools for assessing urban sustainability. Int. J. Urban Sci. 2018, 22, 308-321. [CrossRef]

38. Merino-Saum, A.; Halla, P.; Superti, V.; Boesch, A.; Binder, C.R. Indicators for urban sustainability: Key lessons from a systematic analysis of 67 measurement initiatives. Ecol. Indic. 2020, 119, 106879. [CrossRef]

39. Gan, X.; Fernandez, I.C.; Guo, J.; Wilson, M.; Zhao, Y.; Zhou, B.; Wu, J. When to use what: Methods for weighting and aggregating sustainability indicators. Ecol. Indic. 2017, 81, 491-502. [CrossRef]

40. Sharifi, A.; Dawodu, A.; Cheshmehzangi, A. Neighborhood Sustainability Assessment Tools: A Review of Success Factors. J. Clean. Prod. 2021, 67, 125912. [CrossRef]

41. Tao, Y.; Li, F.; Crittenden, J.; Lu, Z.; Ou, W.; Song, Y. Measuring urban environmental sustainability performance in China: A multi-scale comparison among different cities, urban clusters, and geographic regions. Cities 2019, 94, 200-210. [CrossRef]

42. Farinha, F.; Oliveira, M.J.; Silva, E.M.J.; Lança, R.; Pinheiro, M.D.; Miguel, C. Selection process of sustainable indicators for the Algarve region-OBSERVE project. Sustainability 2019, 11, 444. [CrossRef]

43. Sdoukopoulos, A.; Pitsiava-Latinopoulou, M.; Basbas, S.; Papaioannou, P. Measuring progress towards transport sustainability through indicators: Analysis and metrics of the main indicator initiatives. Transp. Res. Part D Transp. Environ. 2019, 67, 316-333. [CrossRef]

44. Shi, Y.; Ge, X.; Yuan, X.; Wang, Q.; Kellett, J.; Li, F.; Ba, K. An Integrated Indicator System and Evaluation Model for Regional Sustainable Development. Sustainability 2019, 11, 2183. [CrossRef]

45. Marquez-Ballesteros, M.J.; Mora-López, L.; Lloret-Gallego, P.; Sumper, A.; Sidrach-de-Cardona, M. Measuring urban energy sustainability and its application to two Spanish cities: Malaga and Barcelona. Sustain. Cities Soc. 2019, 45, 335-347. [CrossRef] 